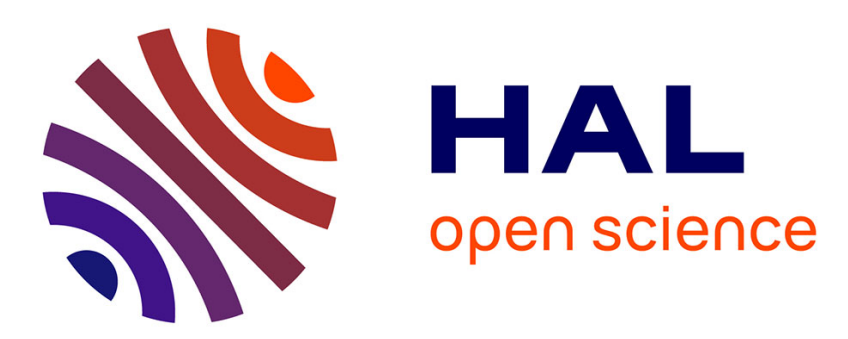

\title{
Evidence for homoploid speciation in Phytophthora alni supports taxonomic reclassification in this species complex
}

Claude Husson, Jaime Aguayo, Cécile Revellin, Pascal Frey, Renaud Ioos, Benoit Marçais

\section{To cite this version:}

Claude Husson, Jaime Aguayo, Cécile Revellin, Pascal Frey, Renaud Ioos, et al.. Evidence for homoploid speciation in Phytophthora alni supports taxonomic reclassification in this species complex. Fungal Genetics and Biology, 2015, 77, pp.12-21. 10.1016/j.fgb.2015.02.013 . hal-01269090

\section{HAL Id: hal-01269090 https://hal.science/hal-01269090}

Submitted on 5 Apr 2019

HAL is a multi-disciplinary open access archive for the deposit and dissemination of scientific research documents, whether they are published or not. The documents may come from teaching and research institutions in France or abroad, or from public or private research centers.
L'archive ouverte pluridisciplinaire HAL, est destinée au dépôt et à la diffusion de documents scientifiques de niveau recherche, publiés ou non, émanant des établissements d'enseignement et de recherche français ou étrangers, des laboratoires publics ou privés. 


\title{
Evidence of homoploid speciation in Phytophthora alni supports reclassification in this species complex
}

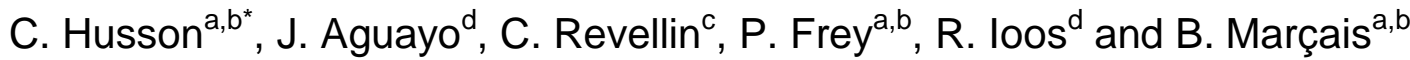

aINRA, UMR1136 Interactions Arbres-Microorganismes, F-54280 Champenoux, France

bUniversité de Lorraine, UMR1136 Interactions Arbres-Microorganismes, F-54500

Vandoeuvre-les-Nancy, France

'INRA, UMR1347 Agroécologie, F-21000 Dijon, France

dANSES Laboratoire de la Santé des Végétaux, Unité de Mycologie, Domaine de

Pixérécourt, F-54220 Malzéville, France

${ }^{*}$ Corresponding author. Fax: +33 383394069

E-mail addresses: claude.husson@nancy.inra.fr (C. Husson), jaime.aguayo@anses.fr (J. Aguayo), cecile.revellin@dijon.inra.fr (C. Revellin), pascal.frey@nancy.inra.fr (P. Frey), renaud.ioos@anses.fr (R. loos),marcais@nancy.inra.fr (B. Marçais)

Keywords: Phytophthora alni; ploidy; interspecific hybridization; flow cytometry; Real-time PCR; homoploid speciation

\section{Abstract}

Alder decline has been a problem along European watercourses since the early 1990's. Hybridization was identified as the main cause of this emerging disease. Indeed, the causal agent, a soil-borne pathogen named Phytophthora alni subsp. alni (Paa) is the result of interspecific hybridization between two taxa, Phytophthora alni subsp. multiformis (Pam) and Phytophthora alni subsp. uniformis (Pau), initially identified as subspecies of Paa. The aim of this work was to characterize the ploidy level within the $P$. alni complex that is presently poorly understood. For that, we used two complementary approaches for a set of 31 isolates of Paa, Pam and Pau: i) comparison of the genome size estimated by flow cytometry and ii) quantification of allele copy number of three single-copy nuclear genes using allele-specific real-time PCR. Relative quantification of alleles of the three single-copy genes showed that the copy number of a given allele in Paa was systematically half that of its parents Pau or Pam. Moreover, DNA content estimated by flow cytometry in Paa was equal to half the sum of those in Pam and Pau. Our results therefore suggest that the hybrid $P a a$ is an allotriploid species, containing half of the genome of each of its parents Pam and $P a u$, which in turn are considered to be allotetraploid and diploid, respectively. Paa is thus the results of an homoploid hybrid speciation. Based on published data and on results from this study, a new formal taxonomic name is proposed for the three taxa Paa, Pam and Pau which are raised to species status and renamed $P$. $\times$ alni, $P . \times$ multiformis and $P$. uniformis respectively. 


\section{Introduction}

Polyploidy is defined as the state of having more than two sets of chromosomes, four being the most common. It generally results from the merging of two distinct species genomes (allopolyploidy, interspecific hybridization) or of the genomes of individuals of the same species (autopolyploidy) (Comai, 2005; Parisod et al., 2010; te Beest et al., 2011). Polyploidization and hybridization are therefore closely interrelated processes. The formation of polyploid organisms is pervasive in plants and, to a lesser extent, in animals: recent genomic studies have demonstrated that almost all angiosperms are polyploid or paleopolyploid, i.e. at least one round of polyploidization event occurred in their ancestry (Arrigo and Barker, 2012; Hegarty and Hiscock, 2008; Otto, 2007). Although it may cause cytological problems such as nuclear disruption, cell enlargement, epigenetic instability and the production of aneuploid cells, being polyploid may bring many advantages as, for example, vigor through heterosis or buffering effect on deleterious mutations through gene redundancy (Comai, 2005). Polyploidy is thus associated with speciation and evolution of Eukaryotes, and may enhance the ability of species to colonize new niches and ecosystems (Giraud et al., 2008; Arrigo and Barker, 2012; Hegarty and Hiscock, 2008; Otto and Whitton, 2000; Otto, 2007).

With the exception of the well-described Saccharomyces genus, occurrence of polyploidy has been poorly investigated in fungi and fungal-like organisms such as oomycetes (Albertin and Marullo, 2012). Yet, polyploidy is considered to have played an important role in the evolution of fungi, in particular in plant mutualists and plant pathogens (Schardl and Craven, 2003). Although interspecific hybridization events have been described in several fungi and oomycetes, particularly in plant pathogens (Albertin and Marullo, 2012; Stukenbrock and McDonald, 2008; Goss et al., 2011; Bertier et al., 2013; Nagel et al., 2013; Man in 't Veld et al., 2012), less than 20 fungal species altogether were clearly identified as polyploids, most of them being allopolyploid (Albertin and Marullo, 2012; Nagel et al., 2013; Olson and Stenlid, 2002; Schardl and Craven, 2003).

Interspecific hybridization could lead to emerging fungal diseases, in particular when the hybrid has the capacity to colonize new hosts (Brasier et al., 2001; Schardl and Craven, 2003; Man in 't Veld et al., 2007; Inderbitzin et al., 2011). A well-described case is the hybrid poplar rust Melampsora $\times$ columbiana which has threatened poplar plantations in the USA, and combines the host ranges of its two parents, i.e. Populus deltoides, $P$. trichocarpa and $P$. xinteramericana (Newcombe et al., 2000; Newcombe et al., 2001). Even if most described hybrids of fungal and fungal-like plant pathogens seem to have little economic or ecological consequences, their importance remains underestimated (Olson and Stenlid, 2002; Bertier et al., 2013). Indeed, the likelihood of hybridization between allopatric species has been hypothesized to be high because they did not evolve barriers to inter-fertility (Brasier et al., 2000). Moreover, encounters between taxonomic species of allopatric origin could increase in frequency through rising global trade which efficiently disperses pathogens around the world (Brasier, 1995; Brasier, 2000; Desprez-Loustau, 2009). Finally, due to their genome plasticity facilitating genome merging, fungi and oomycetes appears to be good candidates for hybridization (Albertin and Marullo, 2012).

The alder decline observed along European watercourses since the early 1990's is an example of an interspecific hybridization event in oomycetes through polyploidization that led to important damage in natural ecosystems (Brasier et al., 1995; Gibbs et al., 1999). Although the decline is strongly influenced by climate (Thoirain et al., 2007; Aguayo et al., 2014), interspecific hybridization has been found to be the main cause of this emerging disease. Indeed, based on abnormal cytological behavior and on polymorphic sites in the internal transcribed spacer (ITS) region, the causal pathogen was determined to be a polyploid hybrid taxon. Two different types of variants exhibiting phenotypically and genetically distinct traits were identified and hypothesized to result from genetic breakdown or back-cross products of the initial hybrid (Brasier et al., 1999). The three taxa were then 
designated as subspecies, Phytophthora alni subsp. alni (Paa, the most aggressive subspecies) and the 2 variants $P$. alni subsp. uniformis ( $P a u)$ and $P$. alni subsp. multiformis (Pam) (Brasier et al., 2004). After counting the chromosomes by light microscopy, Brasier et al. (1999) concluded that the hybrid Paa was near tetraploid ( $n=18-22$, inferred karyotype ca $4 n+2)$, Pam between diploid and tetraploid ( $n=13-18$, inferred karyotype from $2 n+4$ to $2 n+7$ ) and Pau near diploid ( $n=11-13$, inferred karyotype ca $2 n+2)$, the latter exhibiting rather high phenotypic and genetic uniformity compared to the two other subspecies.

However, subsequent analyses of sequence polymorphism at four single-copy nuclear genes (ASF-like, GPA1, RAS-Ypt and TRP1) and two mitochondrial genes (cox1 and nadh1) (loos et al., 2006), at several microsatellite loci (loos et al., 2007a) and at the elicitin genes (loos et al., 2007b) showed that Pau and Pam were not variants of Paa but its progenitors. The expression patterns for nuclear encoded isozymes such as glucose-phosphate isomerase (Gpi) and malate dehydrogenase (Mdh-1 and Mdh-2) brought additional support to this scheme (Brasier et al., 2004; Bakonyi et al., 2007). These results were also confirmed by comparison of mitochondrial DNA RFLP pattern between the taxa of the $P$. alni complex (Nagy et al., 2003; loos et al., 2006).

The status of Pau as a diploid oomycete without hybrid origin was confirmed by loos et al. (2006). Furthermore, Aguayo et al. (2013) showed that it is indigenous in North America where it exists independently of Paa. By contrast, the ploidy status of Paa and Pam appeared more complex. A unique allelic pattern was found for the four single-copy nuclear genes mentioned above. Each gene exhibited three different alleles named PAU, PAM1 and PAM2 (loos et al., 2006): while for each of the studied genes all Pau isolates exhibited a single allele PAU, all Pam isolates exhibited both alleles PAM1 and PAM2 and all isolates of the hybrid Paa exhibited the three alleles. The authors concluded that Pam might be a cryptic polyploid taxon (loos et al., 2006; loos et al., 2007b). The case of Paa, with three alleles at each locus, also did not fit with the near tetraploid status initially described by Brasier et al. (1999). As a result, the ploidy levels of the three taxa of the $P$. alni complex remain uncertain even though this knowledge is critical to characterize genetically populations and to evaluate their evolutionary potential. In parallel, the designation of Paa, Pau and Pam as subspecies does not appear to be correct anymore.

Flow cytometry is a well-proven technique to estimate the DNA content of individual nuclei in plant or animal species (Doležel et Bartoš, 2005; Walker et al., 2006; Jeyaprakash and Hoy, 2009), as well as in fungi and oomycete species, including Phytophthora spp. (Bertier et al., 2013; Catal et al., 2010; Vercauteren et al., 2011) and hence ploidy level by using internal standards with known DNA content or ploidy (D'Hondt et al., 2011; Bertier et al., 2013; Burson et al., 2012). More recently, a method based on real-time quantitative PCR has been developed for estimating ploidy levels. Based on the quantification of allele copy number of a single-copy gene DNA using calibrated solutions with known concentrations of the target sequence, the method proved to be efficient with various organisms (Jeyaprakash and Hoy, 2009; Mounsey et al., 2012; Wilhelm et al., 2003).

The aim of this study was therefore to determine the respective ploidy level of the hybrid Paa and its progenitors using a combination of two approaches, i.e. comparing their genome size by flow cytometry and the allele copy number for three single-copy nuclear genes using real-time PCR probes specific for the PAU, PAM1 and PAM2 alleles. Finally, based on published data and on results from this study, a new formal taxonomic name is proposed for the three taxa of the $P$. alni complex that were hitherto designated as subspecies. 


\section{Materials and methods}

\subsection{Isolate collection}

Phytophthora isolates used in this study are detailed in Table 1. P. alni strains from France were isolated from inner bark lesions of alder trees using V8 juice agar selective medium as described in Aguayo et al. (2013). The remaining isolates were provided by colleagues from Europe or the USA. Taxonomic identification was performed based on morphological characters and using a set of taxon-specific primers, i.e. SCAR-based primer pairs PA-F/R, PAM-F/R (loos et al., 2005) and allele-specific primer pairs TRP-PAU-F/-R, RAS-PAM1-F/-R, RAS-PAM2-F/-R, RAS-PAU-F/R (loos et al., 2006). Isolates of $P$. ramorum were added in our studies as a standard since the genome size of this species is known (Tyler et al., 2006; Vercauteren et al., 2011). All isolates were maintained on V8 juice agar medium containing rifampicin $\left(10 \mathrm{mg} \mathrm{L}^{-1}\right)$ at $20^{\circ} \mathrm{C}$ in darkness until use.

Table 1: Isolates used in this study.

\begin{tabular}{|c|c|c|c|c|c|c|c|}
\hline \multirow[b]{2}{*}{ Taxon } & \multirow[b]{2}{*}{ Name } & \multirow[b]{2}{*}{$\begin{array}{l}\text { Date of } \\
\text { isolation }\end{array}$} & \multirow[b]{2}{*}{ Host } & \multirow[b]{2}{*}{ Origin } & \multirow[b]{2}{*}{ Supplier (original code) } & \multicolumn{2}{|c|}{ Analysis using : } \\
\hline & & & & & & $\begin{array}{c}\text { Flow } \\
\text { cytometry }\end{array}$ & $\begin{array}{l}\text { Real- } \\
\text { time } \\
\text { PCR }\end{array}$ \\
\hline Paa & PAA85 $^{\mathrm{a}}$ & 1996 & Alnus glutinosa & France & INRA Nancy (P834) & $*$ & $*$ \\
\hline Paa & PAA $101^{a}$ & 2003 & A. glutinosa & France & INRA Nancy & $*$ & $*$ \\
\hline Paa & PAA129 & 2003 & A. glutinosa & France & INRA Bordeaux (703) & $*$ & $*$ \\
\hline Paa & PAA354 ${ }^{\text {a }}$ & 2008 & A. glutinosa & France & INRA Nancy & $*$ & $*$ \\
\hline Paa & PAA563 & 2009 & A. glutinosa & Belgium & INRA Nancy & $*$ & \\
\hline Paa & PAA174 ${ }^{a}$ & 2004 & A. glutinosa & Germany & INRA Nancy & * & $*$ \\
\hline Paa & PAA661 & 2005 & A. glutinosa & Poland & L. Orlikowski (Paa8) & $*$ & \\
\hline Paa & PAA782 ${ }^{a}$ & 2009 & A. glutinosa & Spain & A. Pérez-Sierra (Ps-786) & $*$ & $*$ \\
\hline Pam & PAM872 $^{a}$ & 2007 & A. glutinosa & France & INRA Nancy (07dur6) & & $*$ \\
\hline Pam & PAM391 $^{a}$ & 2009 & A. incana & France & INRA Nancy & & $*$ \\
\hline Pam & PAM393 $^{a}$ & 2009 & A. incana & France & INRA Nancy & $*$ & $*$ \\
\hline Pam & PAM396 $^{a}$ & 2009 & A. incana & France & INRA Nancy & $*$ & $*$ \\
\hline Pam & PAM444 & 2009 & A. glutinosa & France & INRA Nancy & & $*$ \\
\hline Pam & PAM71 ${ }^{a}$ & - & A. glutinosa & Netherlands & W. Man in 't Veld (W1139) & $*$ & $*$ \\
\hline Pam & PAM90 & 1998 & A. glutinosa & Netherlands & C. Brasier (P972) & $*$ & \\
\hline Pau & PAU60 & 1999 & A. glutinosa & France & J.C. Streito (AULO28) & $*$ & \\
\hline Pau & PAU300 ${ }^{a}$ & 2008 & A. glutinosa & France & INRA Nancy & $*$ & $*$ \\
\hline $\mathrm{Pau}$ & PAU333 ${ }^{a}$ & 2008 & A. glutinosa & France & INRA Nancy & $*$ & $*$ \\
\hline Pau & PAU542 ${ }^{a}$ & 2009 & A. glutinosa & France & INRA Nancy & $*$ & $*$ \\
\hline Pau & PAU624 ${ }^{a}$ & 2009 & A. glutinosa & France & INRA Nancy & $*$ & $*$ \\
\hline Pau & PAU338 & 2008 & A. glutinosa & France & INRA Nancy & $*$ & \\
\hline Pau & PAU187 & 2001 & A. glutinosa & Belgique & A. Chandelier (2276) & $*$ & \\
\hline Pau & PAU89 & 2000 & A. cordata & Italie & P. Capretti (CBS109280) & $*$ & \\
\hline Pau & PAU142 ${ }^{a}$ & - & A. glutinosa & Slovenia & A. Munda (Phy-A-SLO) & $*$ & $*$ \\
\hline Pau & PAU768 & 2010 & A. incana & USA & G. Adams (QC Bowl 8A) & $*$ & \\
\hline Pau & PAU781 & 2009 & A. glutinosa & Spain & C. Pintos-Varela (685A) & $*$ & \\
\hline Pau & PAU774 & 2010 & A. glutinosa & USA & G. Adams (BLb8atwigs) & $*$ & $*$ \\
\hline Pau & PAU777 & 2010 & A. glutinosa & USA & G. Adams (M54b2) & $*$ & \\
\hline $\mathrm{Pa}$ & PA340 & 2008 & A. glutinosa & France & INRA Nancy & $*$ & \\
\hline $\mathrm{Pa}$ & PA454 & 2005 & A. glutinosa & France & INRA Nancy & & \\
\hline $\mathrm{Pa}$ & PA616 & 2009 & A. glutinosa & France & INRA Nancy & $*$ & \\
\hline$P$.ramorum & F001 & 2002 & Rhododendron sp. & France & INRA Nancy & $*$ & \\
\hline P. ramorum & F002 & 2002 & Rhododendron sp. & France & INRA Nancy & $*$ & \\
\hline
\end{tabular}

Note. Paa, Phytophthora alni subsp. alni; Pam, P. alni subsp. multiformis; Pau, P. alni subsp. uniformis, $P a, P$. alni isolates that could not be clearly attributed to a taxon (see Table 3 ).

${ }^{a}$ isolates used for primer/probe specificity tests. 


\subsection{Phytophthora zoospore suspensions}

Approximately thirty 5-mm agar plugs taken from the growing edge of a 3-day-old colony were placed into Petri dishes containing river water filtered through a $10-\mu \mathrm{m}$ Omnipore $^{\mathrm{TM}}$ membrane filter (JCWP04700, Millipore, Molsheim, France). Water collected from river is essential for inducing $P$. alni zoospores production. Plates were incubated at $20^{\circ} \mathrm{C}$ in darkness and the river water was changed daily. As soon as sporangia were produced, i.e. 2-3 days later, plugs were transferred into a new plate containing $4^{\circ} \mathrm{C}$ ultrapure water and exposed 1-2 $\mathrm{h}$ to daylight at room temperature in order to stimulate zoospore release. The zoospore suspensions were then filtered through a $45 \mu \mathrm{m}$ sieve to remove mycelium, transferred into a $50 \mathrm{~mL}$ Falcon ${ }^{\circledR}$ tube, vortexed for 1 min and finally stored for 1 hour at $4^{\circ} \mathrm{C}$ to induce zoospores encystement. Zoospores were then retrieved by filtering the suspension through a $10-\mu \mathrm{m}$ Omnipore ${ }^{\mathrm{TM}}$ membrane filter, and filters were placed into a 14 $\mathrm{mL}$ Falcon ${ }^{\circledR}$ tube containing $3 \mathrm{~mL}$ Tris-Hcl EDTA buffer (10 mM Tris-HCl pH 8, $10 \mathrm{mM}$ EDTA, $100 \mathrm{mM} \mathrm{NaCl}$, Anderson et al., 2010). The tubes were vortexed for $1 \mathrm{~min}$ to release zoospores from filters and to increase zoospore concentration in the buffer. The concentration of zoospores was determined by using a haemocytometer under a microscope and the suspension was diluted to appropriate concentrations according to the technique used.

\subsection{DNA extraction}

For six isolates of each of Paa, Pau and Pam (Table 1), $2 \mathrm{~mL}$ microtubes containing $200 \mu \mathrm{L}$ Tris-Hcl EDTA buffer and $10,000,20,000,40,000$ or 80,000 zoospores were produced. DNA extractions from the zoospore suspensions or from pure fresh mycelia grown on V8 agar medium (for taxonomic identification) were performed using the DNeasy Plant mini-kit (Qiagen, Courtaboeuf, France). One 3-mm tungsten carbide bead and twenty 2-mm glass beads were added into the microtubes and the samples were ground for $30 \mathrm{~s}$ at a frequency of $30 \mathrm{~Hz}$ using a bead-beater (TissueLyser, Qiagen, France). AP1 buffer (400 $\mu \mathrm{L})$ was added in each tube and the samples were ground again for $30 \mathrm{~s}$. DNA was then extracted following the manufacturer's instructions except that incubation period with the AP1 lysis buffer was extended to 1 hour at $65^{\circ} \mathrm{C}$. Finally, DNA was eluted in a final volume of 200 $\mu \mathrm{L} A E$ buffer. Each series of DNA extraction included samples from the three taxa. Since the aim was not to characterize individual strains, but the $P$. alni taxa, only one replicate per strain and zoospore concentration was performed.

\subsection{Design of allele-specific primer pairs and probes for the three single-copy genes}

Sequences of single-copy nuclear genes ASF-like, GPA1 and RAS-Ypt from Pam (PAM71 and PAM54) and Pau (PAU60) deposited in Genbank by loos et al. (2006) were analyzed using Sequencher 4.7 (Gene Codes Corporation, USA). Primer pairs and duallabelled probes specific to alleles PAU, PAM1 and PAM2 were designed for each single-copy gene using Primer 3 software (Rozen and Skaletsky, 2000) and Beacon Designer software (Premier Biosoft, Palo Alto, CA, USA) (Table 2).

Specificity of primer pairs was assessed by conventional PCR on DNA samples of 15 Paa, Pam and Pau isolates (Table 1). PCRs were carried out in a $20 \mu \mathrm{L}$ final reaction volume containing ultrapure water, 1x Taq DNA polymerase buffer (Sigma-Aldrich, Lyon, France), 2 $\mathrm{mM} \mathrm{MgCl} 2,0.45 \mu \mathrm{M}$ of each primer, $200 \mu \mathrm{M}$ dNTP, 0.7 unit of Taq DNA polymerase (SigmaAldrich) and $2 \mu \mathrm{L}$ of template DNA (2-10 ng). They were performed by using a PTC-200 Peltier Thermal Cycler (MJ Research, Bio-Rad, Marnes-la-Coquette, France) and included an initial denaturation at $95^{\circ} \mathrm{C}$ for 3 min followed by 35 cycles at $95^{\circ} \mathrm{C}$ for $30 \mathrm{~s}, 62^{\circ} \mathrm{C}$ for $30 \mathrm{~s}$, $72^{\circ} \mathrm{C}$ for $60 \mathrm{~s}$ and a final extension at $72^{\circ} \mathrm{C}$ for $10 \mathrm{~min}$. PCR products were separated by a $1-$ $\mathrm{h}$ electrophoresis in $1 \%$ agarose gels in TBE buffer at $4 \mathrm{~V} \mathrm{~cm}^{-1}$ and visualized by U.V. exposition following ethidium bromide staining. The fragment sizes were estimated by 
comparison with a 100-bp DNA ladder (Invitrogen). Images were recorded with a GelDoc 2000 system (Biorad).

Table 2: List and characteristic of forward (-F) and reverse (-R) primers and probes (P) developed in this study, except * which were designed in loos et al. (2006).

\begin{tabular}{|c|c|c|c|}
\hline Name & Sequence $\left(5^{\prime}-3^{\prime}\right)$ & $\begin{array}{l}\text { DNA ten } \\
\text { gene }\end{array}$ & $\begin{array}{l}\text { plate region } \\
\text { allele }\end{array}$ \\
\hline AL-ASF-PAU-F & ACCGCCACAACATCCACT & ASF-like & ASF-PAU \\
\hline AL-ASF-PAU-R & GCACGGGACCTACGAGGA & ASF-like & ASF-PAU \\
\hline AL-ASF-PAM1-F & САССАССАССАСААТАТСТСС & ASF-like & ASF-PAM1 \\
\hline AL-ASF-PAM1-R & ACAAGCACTTCCTCCAGCA & ASF-like & ASF-PAM1 \\
\hline AL-ASF-PAM2-F & ACCGCCATCACCACCATA & ASF-like & ASF-PAM2 \\
\hline AL-ASF-PAM2-R & CACGAGAACTTCCTCCAGCA & ASF-like & ASF-PAM2 \\
\hline AL-ASF-P & FAM- AGGACGAGAGCCGCGACCAG-BHQ1 & ASF-like & ASF-PAU/-PAM1/-PAM2 \\
\hline AL-GPA-PAU-R & GTCCTCGCAACTCCCACTAT & GPA1 & GPA-PAU \\
\hline AL-GPA-PAM1-R & ACTGCGAGCAAGTCTACGG & GPA1 & GPA-PAM1 \\
\hline AL-GPA-PAM2-R & CACCGCGAACAAGTCAAC & GPA1 & GPA-PAM2 \\
\hline AL-GPA-F & AAGAACGAGGAGGCTCACC & GPA1 & GPA-PAU/-PAM1/-PAM2 \\
\hline AL-GPA-P & FAM-CTGCTGCTGCTGGGAGCTGG-BHQ1 & GPA1 & GPA-PAU/-PAM1/-PAM2 \\
\hline AL-RAS-PAU-F & AACATGGCTACGGTTTGCTC & $R A S-Y p t$ & RAS-PAU \\
\hline AL-RAS-PAU-R & GTCCCACTACAGTTCCGAATAACC & $R A S-Y p t$ & RAS-PAU \\
\hline AL-RAS-PAM1-F & GCTGACATTATCGTGCTCGT & $R A S-Y p t$ & RAS-PAM1 \\
\hline AL-RAS-PAM1-R & GAAAGCGGACACCAGTAAGC & $R A S-Y p t$ & RAS-PAM1 \\
\hline AL-RAS-PAM2-F & ACTCCGATTGCTGACGTTGT & $R A S-Y p t$ & RAS-PAM2 \\
\hline AL-RAS-PAM2-R & GCGTACGTCAGTAAGCTCCA & $R A S-Y p t$ & RAS-PAM2 \\
\hline AL-RAS-P & FAM-ACGATCGAGCTGGACGGCA-BHQ1 & $R A S-Y p t$ & RAS-PAU/-PAM1/-PAM2 \\
\hline TRP-PAU-F* & GTGCGTCGCTAGCCCATCA & $T R P 1$ & TRP-PAU \\
\hline TRP-PAU-R ${ }^{*}$ & CGCCTACAGAGCATCATAG & TRP1 & TRP-PAU \\
\hline RAS-PAM1-F* & AGAGGGATATATTTGAGGTT & $R A S-Y p t$ & RAS-PAM1 \\
\hline RAS-PAM1-R* & GTTGGACCCGGGACGGTCTTC & $R A S-Y p t$ & RAS-PAM1 \\
\hline RAS-PAM2-F* & AGAGGGATATATTTGCGGCT & $R A S-Y p t$ & RAS-PAM2 \\
\hline RAS-PAM2- $R^{*}$ & TCAGCAATCGGAGAGCAAGCT & $R A S-Y p t$ & RAS-PAM2 \\
\hline RAS-PAU-F* & ATTTACTTGCAGCCGCAGGCT & $R A S-Y p t$ & RAS-PAU \\
\hline RAS-PAU-R* & ACCTAGGGCAGACAAGCTAGTC & $R A S-Y p t$ & RAS-PAU \\
\hline
\end{tabular}

\subsection{Quantification of allele copy number of three single-copy genes}

Quantification of allele copy number in the three taxa was performed by real-time PCR assays in a $20 \mu \mathrm{l}$ reaction volume consisting of ultra-pure water, $10 \mu \mathrm{L}$ of Brilliant III UltraFast QPCR Master Mix (Agilent, Les Ulis, France) $0.3 \mu \mathrm{M}$ of each primer, $0.1 \mu \mathrm{M}$ of duallabelled probe, $0.15 \mathrm{U}$ of Uracil-N-Glycosylase (UNG), $30 \mathrm{nM}$ of ROX reference dye and $2 \mu \mathrm{l}$ of template DNA. Real-time PCR was carried out in a Stratagene Mx3005P and using the Mx-Pro software version 4.1 (Agilent). The PCR thermal cycling program included an initial step for UNG activation for 2 min at $50^{\circ} \mathrm{C}$, a Taq polymerase activation step for 3 min at $95^{\circ} \mathrm{C}$ followed by 45 cycles of denaturation at $95^{\circ} \mathrm{C}$ for $15 \mathrm{~s}$, and annealing / elongation at $65^{\circ} \mathrm{C}$ for $50 \mathrm{~s}$.

The experiment was designed in order to compare without bias the allele copy number between Paa and its parents, Pam and Pau, for each of the three studied genes, ASF-like, GPA1 and RAS-Ypt. Therefore, to avoid any extraction bias, an equal number of strains of $\mathrm{Paa}$ and of either Pau or Pam was included in each DNA extraction (5 different DNA 
extractions). Twenty-four DNA samples were studied for each taxon, i.e. 6 isolates * 4 different concentrations (from 10,000 to 80,000 zoospores in $200 \mu \mathrm{L}$ ). PCR was repeated twice for each DNA sample. Real-time PCR assays were performed on 96-well plates containing either all the DNA samples of Paa and Pau or all those of Paa and Pam (2 taxa $\mathrm{x}$ 24 DNA samples $\times 2$ replicates for each plate). The former were amplified with primers and probes specific for allele PAU while the latter were amplified with primers and probes specific for alleles PAM1 or PAM2 (Table 2). The amplification efficiency of the two studied taxa for each PCR assay was computed as the mean efficiency estimated by the Mx-Pro software with the current default baseline algorithm. Only the PCR assay that exhibited less than $5 \%$ difference in the amplification efficiency of the two compared taxa were retained for further analysis.

The $\mathrm{Ct}$ values were analyzed by the following Bayesian model with WinBUGS 1.4:

$\mathrm{CTi}=\mu+\alpha_{1 i} \times$ Extraction $_{\mathrm{i}}+\alpha_{2 \mathrm{i}} \times$ Primer $_{\mathrm{i}}+\alpha_{3 \mathrm{i}} \times$ Parent $_{\mathrm{i}}+\alpha_{4 \mathrm{i}} \times$ Primer $_{\mathrm{i}} \times$ Parent $_{\mathrm{i}}+(\mathrm{SI}+$ $\beta_{1 i} \times$ Extraction $_{i}+\beta_{2 i} \times$ Primer $_{i}+\beta_{2 i} \times$ Parent $\left._{i}\right) \times$ concentr $_{i}+$ Isolate $_{i}+\varepsilon_{i}$

with $\mu$ and $\mathrm{SI}$, the mean intercept and slope, Extraction ${ }_{i}$, the DNA extraction number of the sample (1-5), Primer ${ }_{i}$, the primer pair used (9 combinations of the 3 genes and of the 3 alleles), Parent $\mathrm{i}_{\mathrm{i}}$, whether the taxon was the hybrid Paa or Pam/Pau (0-1), concentr, the zoospore concentration and Isolate $e_{i}$ a random isolate effect that followed a normal distribution.

Non informative priors were assigned to the model parameters with a normal distribution $\mathrm{N}(0,1 \mathrm{e} 04)$ and to the variances, residual and isolate random variable, with a gamma distribution $\mathrm{G}(0.001,0.05)$. Three parallel chains with different initial parameter values were run for 7500 iteration following a burn-in of 3000 with a thinning of 10 . The convergence was checked by Gelman-Rubin test ( $R_{\text {hat }}$ were close to 1$)$.

The ratio of allele copy number in Paa versus the parents, Pau or Pam, was computed for each primer pair (gene $x$ allele combination) as $(1+E)^{\alpha_{3 i}}$, with $E$ the amplification efficiency and $\alpha_{3 i}$, the coefficient computed for the "Parent" effect. Indeed, the amplification during a PCR run, $\mathrm{N}_{\mathrm{Ct}} / \mathrm{N}_{0}$, can be expressed as $(1+\mathrm{E})^{\mathrm{Ct}}$, with $\mathrm{N}_{0}$, the initial allele copy number, $\mathrm{N}_{\mathrm{Ct}}$, the copy number at the threshold and $\mathrm{Ct}$, the threshold cycle. As primer pairs were amplified in the same run for Paa and the parents, $N_{\mathrm{Ct}}$ is the same. The ratio of allele copy number in the parent Pam or Pau versus Paa for a primer pair will thus be $(1+\mathrm{E})^{\mathrm{Ct}} \mathrm{Paa}^{-}$

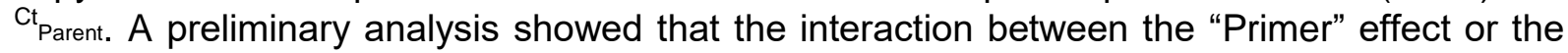
"concentr" effect and the "Parent" effect were not significant. Thus, for each DNA extraction, primer pair, and zoospore concentration, the difference in Ct between Paa and either parent is equal to $a_{3 i}$. The ratio of allele copy number in the parental taxa versus Paa, i.e. $(1+E)^{a_{3 i}}$, was monitored during the MCMC run. These ratios will be named respectively Pau:Paa and Pam:Paa hereafter.

\subsection{Estimation of nuclear DNA content by flow cytometry}

Suspensions of about $2.10^{5}$ zoospores per $\mathrm{mL}$ were obtained for each Phytophthora isolate (Table 1). They were filtered through a $10 \mu \mathrm{m}$ Partec CellTrics ${ }^{\circledR}$ filter and stained by adding $4.6 \mu \mathrm{L}$ Propidium lodide (PI, Partec, Munster, Germany) and $2 \mu \mathrm{L}$ RNase (100 mg $\mathrm{mL}^{-1}$ ) per $\mathrm{mL}$. After incubation at $4^{\circ} \mathrm{C}$ overnight, $\mathrm{Pl}$-stained nuclei of zoospores were analyzed with a Cyflow blue flow cytometer (Partec $\mathrm{GmbH}$ ) operating a 20-mW solid-state laser $(488 \mathrm{~nm})$. Data analysis was performed using Flomax 2.7 software (Partec $\mathrm{GmbH})$. Forward angle light scattering (FSC), right angle light scattering (SSC) and red fluorescence (emission $630 \mathrm{~nm}$ ) were measured simultaneously. Each measurement was repeated twice per isolate.

Fluorescence intensity histograms were constructed to exhibit a peak of fluorescence linearly correlated with the DNA content in the G1 phase of the cell cycle of the sample analyzed (Doležel and Bartoš, 2005). An analysis of variance (ANOVA) was conducted to 
test the effect of taxon on the peak position, with isolate effect taken into account as a random variable. The model was fitted in a Bayesian framework under WinBUGS 1.4. Non informative priors were assigned to model parameters with a normal distribution $\mathrm{N}(0,1 \mathrm{e} 04)$ and a gamma distribution $\mathrm{G}(0.001,0.05)$ for variances (residual and isolate random variable). Three parallel chains with different initial parameter values were run for 2000 iteration following a burn-in of 2000 with a thinning of 10 . The convergence was checked by Gelman-Rubin test $\left(R_{\text {hat }}\right.$ were close to 1$)$.

Relative DNA content, i.e. ratio between the peak positions of each taxon of $P$. alni complex and $P$. ramorum and ratio of the DNA content in Paa to the sum of DNA content in Pau and Pam were computed and monitored during the MCMC run. The absolute nuclear DNA content and genome size of each taxon of the $P$. alni complex were then determined by comparison with a reference species with known genome size, i.e. $P$. ramorum.

Table 3: Taxonomic identification based on the allele-specific primers of loos et al. (2006) and SCARbased primers of loos et al. (2005).

\begin{tabular}{|c|c|c|c|c|c|c|c|}
\hline Isolates & $\begin{array}{c}\text { RAS- } \\
\text { PAM1-F/R }\end{array}$ & $\begin{array}{c}\text { RAS- } \\
\text { PAM2-F/R }\end{array}$ & $\begin{array}{c}\text { RAS- } \\
\text { PAU-F/R }\end{array}$ & $\begin{array}{l}\text { TRP- } \\
\text { PAU- } \\
\text { F/R }\end{array}$ & $\begin{array}{l}\text { PAM- } \\
\text { F/R }\end{array}$ & PA-F/R & Taxon \\
\hline $\begin{array}{l}\text { PAA85, PAA101, } \\
\text { PAA129, PAA174, } \\
\text { PAA324, PAA563, } \\
\text { PAA661, PAA782 }\end{array}$ & + & + & + & + & + & + & Paa \\
\hline $\begin{array}{l}\text { PAU60, PAU89, } \\
\text { PAU142, PAU187, } \\
\text { PAU300, PAU333, } \\
\text { PAU338, PAU542, } \\
\text { PAU624 }\end{array}$ & - & - & + & + & - & + & Pau \\
\hline $\begin{array}{l}\text { PAM71, PAM90, } \\
\text { PAM391, PAM393, } \\
\text { PAM396, PAM444, } \\
\text { PAM872 }\end{array}$ & + & + & - & - & + & + & Pam \\
\hline PA340 & + & + & + & + & - & + & \\
\hline PA454 & - & - & - & + & - & + & . \\
\hline PA616 & + & + & + & - & + & + & . \\
\hline
\end{tabular}

Note. Paa, Pam and Pau are P. alni subsp. alni, multiformis and uniformis respectively;

PA340, PA454 and PA616 are P. alni isolates that could not be clearly attributed to one of the three taxo.

\section{Results}

\subsection{Taxonomic identification of the isolate collection}

While most tested isolates unambiguously belonged to one of the three taxa described by Brasier et al. (2004) using the set of primer pairs designed by loos et al. $(2005,2006)$, three isolates, PA340, PA454 and PA616, did not present conventional pattern (Table 3). Although these isolates clearly fitted in the $P$. alni complex, based on morphological features and SCAR-based primers pairs, they could not be assigned to a defined taxon. For example, PA340 exhibited a pattern close to Pau but exhibited additional alleles PAM1 and PAM2 at locus RAS-Ypt. On the opposite PA616 was close to Pam but exhibited an additional allele PAU at locus RAS-Ypt. 

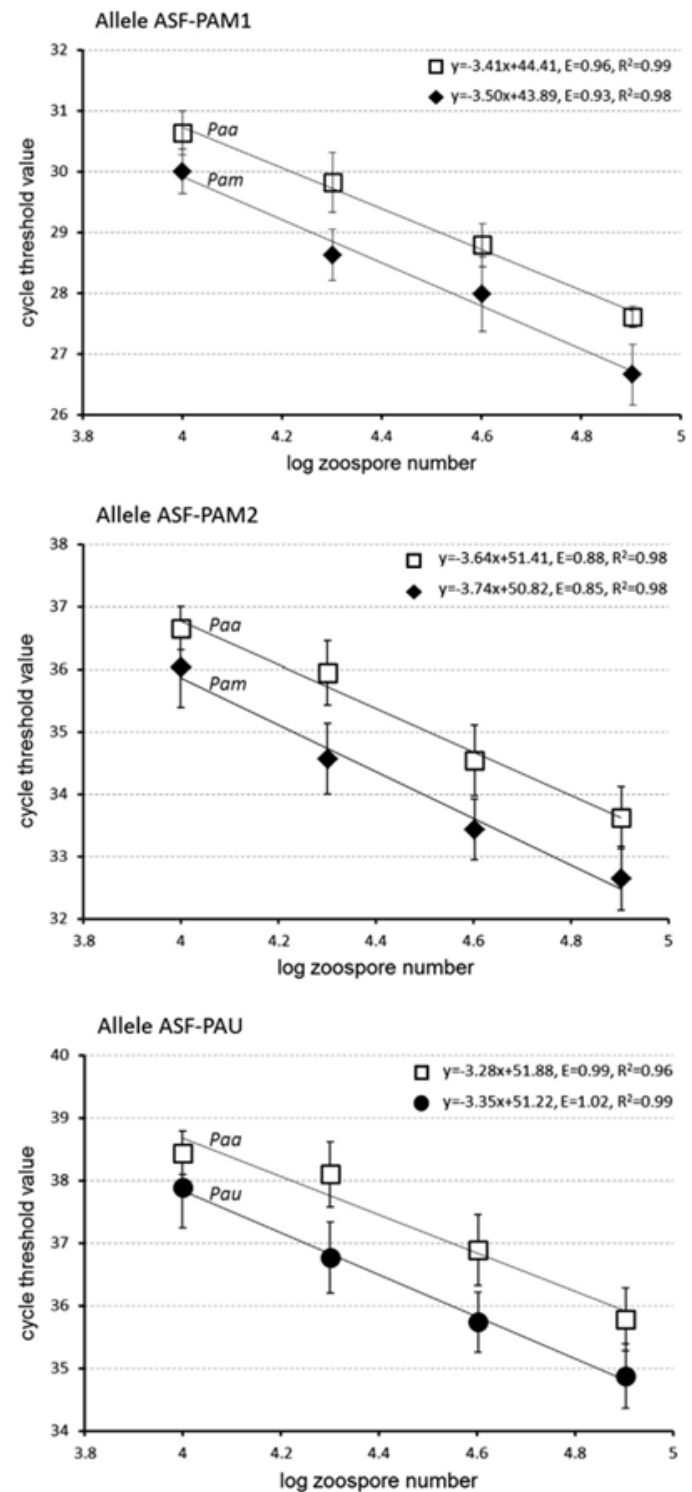

Fig. 1: Cycle threshold values yielded by real-time PCR amplification of the three alleles of the ASF-like gene, ASF-PAM1, ASF-PAM2 and ASFPAU. The taxa are indicated above the standard curves. Paa, Pam and $P a u$ are $P$. alni subsp. alni, multiformis and uniformis isolates, respectively. E, amplification efficiency. Errors bars, 95\% confidence intervals.

\subsection{Quantification of allele copy number of three single-copy genes}

A unique probe for each of the three genes (ASF-like, GPA1 and RAS-Ypt) and a unique forward primer for the GPA1 gene were designed due to the close similarity of the sequences of the three single-copy genes (Table 2).

The specificity of primer pairs designed for real-time PCR was first confirmed by conventional PCR on a set of 15 genomic DNA samples belonging to the three $P$. alni taxa. The primer pairs AL-ASF-PAU-F/-R, AL-GPA-F/AL-GPA-PAU-R and AL-RAS-PAU-F/-R yielded an amplicon of the expected size for the Paa and Pau isolates, i.e. 154, 142 and 196 $\mathrm{bp}$, respectively. No amplicon was obtained for $\mathrm{Pam}$ isolates. PCRs using primer pairs ALASF-PAM1-F/-R, AL-GPA-F/AL-GPA-PAM1-R, AL-RAS-PAM1-F/-R on one hand, and ALASF-PAM2-F/-R, AL-GPA-F/AL-GPA-PAM2-R, AL-RAS-PAM2-F/-R on the other hand 
amplified a DNA fragment of the expected size for the Paa and Pam isolates $(138,127,147$, $141,128,152 \mathrm{bp}$, respectively) and no amplicon for the Pau isolates.

Subsequently, a series of nine allele-specific real-time PCR reactions were carried out and analyzed, each of them quantifying a unique allele from each of the studied gene (three alleles, PAU, PAM1 and PAM2 $x$ three genes). For all studied alleles, DNA from the parental taxa Pau or Pam yielded mean $\mathrm{Ct}$ values that were on average 1 cycle lower than the DNA from the Paa hybrid (Fig. 1). The parent status (Paa versus Pau or Pam), the extraction and the primer pair all had a significant effect on the Ct value ( $p$-values all under 0.001). Zoospore concentration, primer pair x zoospore concentration and extraction $\mathrm{x}$ zoospore concentration interactions and the isolate random factor also induced significant variability $(p-$ values all under 0.001 ). By contrast, the parent status $\mathrm{x}$ primer pair and the parent status $\mathrm{x}$ zoospore concentration interactions had no significant effect on the Ct value (respective pvalue of 0.364 and 0.151 ).

The Pau:Paa or Pam:Paa ratios ranged from 1.95 to 2.29 depending on the primer pair (Table 4). As none of the interactions involving the parent factor significantly influenced the Ct, a global parent species:Paa ratio could be estimated as $2.1(95 \% \mathrm{Cl}[1.6-2.8])$ meaning that the copy number of an allele PAU, PAM1 or PAM2 in Pau or Pam was twice as high as in Paa, regardless of the gene studied.

Table 4: Ratios of allele copy numbers in the three taxa Paa, Pau and Pam (95\% confidence intervals). Paa, Pam and Pau are P. alni subsp. alni, multiformis and uniformis respectively.

\begin{tabular}{lccc}
\hline Gene & $\begin{array}{c}\text { Pau:Paa ratio } \\
\text { for allele PAU }\end{array}$ & $\begin{array}{c}\text { Pam:Paa ratio } \\
\text { for allele PAM1 }\end{array}$ & $\begin{array}{c}\text { Pam:Paa ratio } \\
\text { for allele PAM2 }\end{array}$ \\
\hline ASF-like & $2.29(1.66,3.17)$ & $2.21(1.63,3.03)$ & $2.10(1.58,2.83)$ \\
GPA1 & $1.94(1.50,2.53)$ & $2.10(1.58,2.83)$ & $2.06(1.55,2.74)$ \\
RAS-Ypt & $2.02(1.54,2.67)$ & $2.01(1.53,2.66)$ & $2.06(1.56,2.75)$ \\
\hline
\end{tabular}

\subsection{Flow cytometry analysis}

Flow cytometry analyzes were carried out on 8 Paa, 4 Pam and 13 Pau isolates. Since the zoospore suspensions were produced using river water filtered through a $10 \mu \mathrm{m}$ filter, numerous PI-stained organisms, such as bacteria or protists, were detected in FSC versus SSC plot (Fig. 2, left panel). Based on their densities and sizes, zoospore nuclei were targeted in a selective gate. For each sample, 250 to $3000 \mathrm{PI}$-stained zoospore nuclei were analyzed. A peak of fluorescence was clearly observed in PI fluorescence histograms for all samples (Fig. 2, right panel). The taxon factor significantly influenced peak position (all pvalue < 0.001). The peak positions observed for Paa were in an intermediate position between those observed for Pau and Pam (Fig. 3). The isolates PA340 and PA616 that could not be attributed clearly to one of the taxon had a peak position very similar to Paa. Estimated DNA content of Paa was half the sum of DNA content of its parents with the ratio (Paa peak position / (Pam + Pau peak positions)) equal to 0.51 (95\% Cl [0.49-0.53]). Given that DNA content of $P$. ramorum zoospore nucleus has been estimated by flow cytometry to be $0.146 \mathrm{pg}$ (Vercauteren et al., 2011), the mean nuclear DNA content of Paa, Pam and Pau were respectively estimated at $0.384 \mathrm{pg}(95 \% \mathrm{Cl} 0.327,0.458), 0.453(95 \% \mathrm{Cl}[0.385$, $0.540])$, and $0.303 \mathrm{pg}(95 \% \mathrm{Cl}[0.257,0.361])$. 

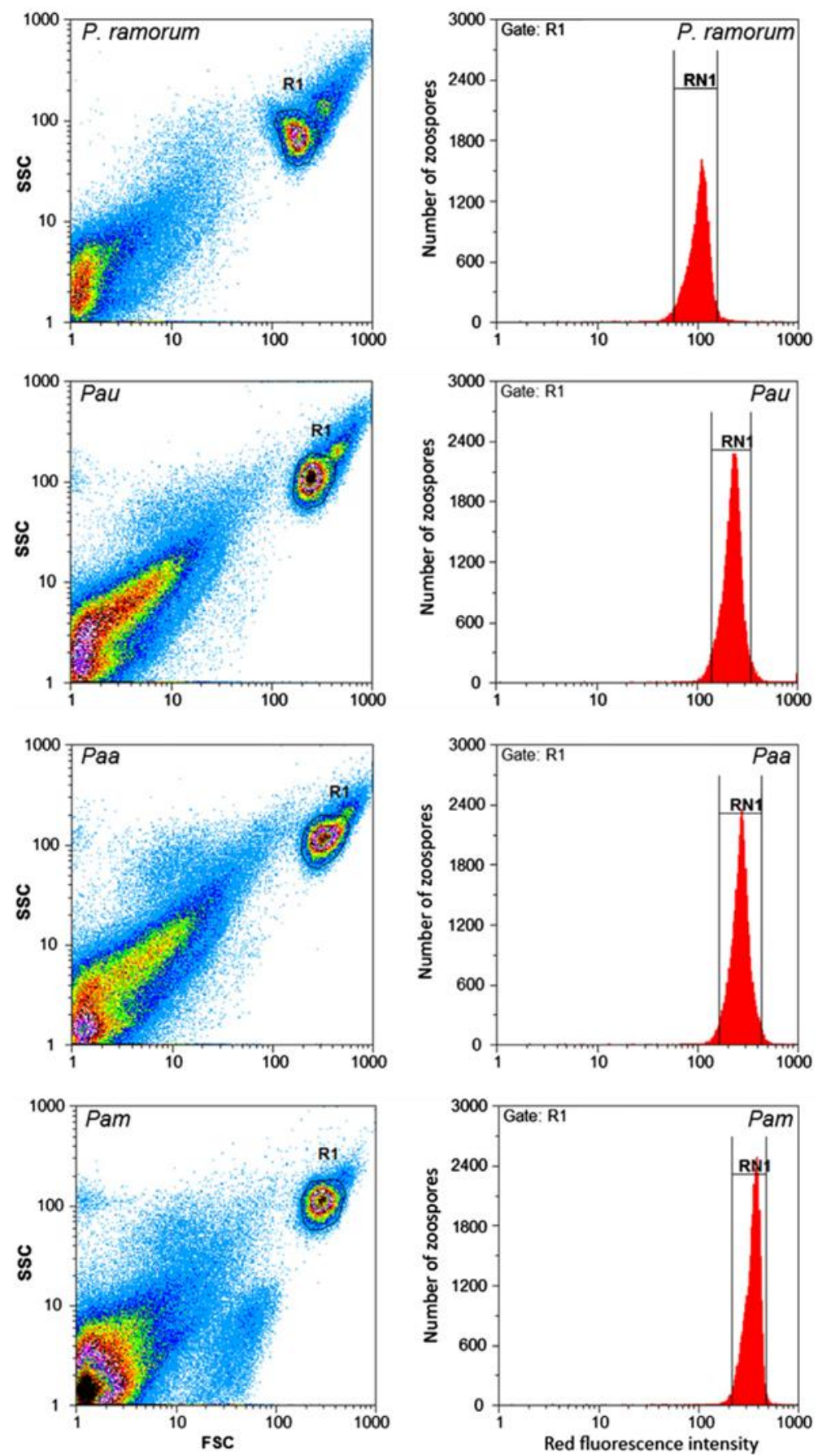

Fig. 2: Flow cytometry analysis of PI-stained zoospore nuclei of Phytophthora sp. isolates. P. ramorum isolate F001; Pau, P. alni subsp. uniformis isolate PAU777; Paa, P. alni subsp. alni isolate PAA174 ; Pam, P. alni subsp. multiformis PAM71. On the left: forward scattering (FSC) versus side scattering (SSC). On the right: histogram of red fluorescence intensity (logarithmic scale). R1, gate used for measuring mean red fluorescence intensity (RN1) emitted by stained nuclei of zoospores in the G1 phase of the cell cycle. 


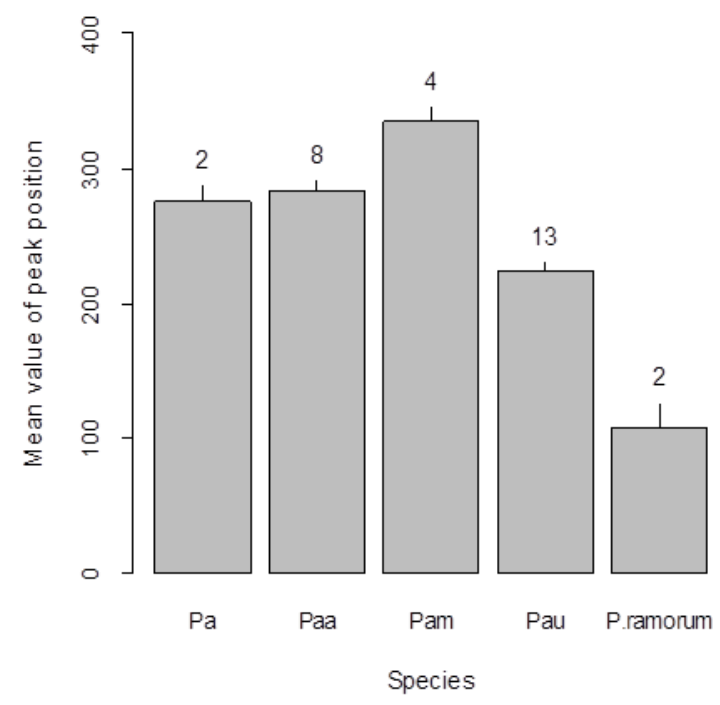

Fig. 3: Red fluorescence emission peak position measured by flow cytometry. Paa, Pam and Pau are P. alni subsp. alni, multiformis and uniformis isolates, respectively. $P a$ isolates could not be assigned clearly to one of the taxon. Errors bars: $95 \%$ confidence intervals. The number of isolates studied is indicated above the bars.

\section{Discussion}

\subsection{Ploidy determination in the $P$. alni complex}

This study brings new insights on the hybridization process that led to Paa through quantitative features. Relative quantification of allele copy number of the three single-copy genes showed that the copy number of a given allele in Paa was systematically half that of its progenitors $\mathrm{Pau}$ or Pam. This ratio is particularly reliable since it was confirmed for three alleles (PAU, PAM1, PAM2) of three different single-copy genes (ASF-like, GPA1, RAS-Ypt), regardless of zoospore concentration and primer pairs / probes used. Our results suggest therefore that the hybrid Paa contains half of the genome of each parent Pam and Pau. This result is confirmed by the DNA content estimate assessed by flow cytometry on a panel of Paa, Pam and Pau isolates. The total DNA content of Paa was equal to half the sum of those of Pam and Pau, suggesting that the Paa genome is the addition of half the Pam and half the Pau genomes.

loos et al. (2006) suggested that Pam could be either a tetraploid taxon or a diploid taxon resulting from homoploid speciation i.e. a hybridization that occurred without change in chromosome number. We showed that Pam has transmitted to Paa half of its genome while transmitting at the same time both the PAM1 and PAM2 alleles at each of the three single copy genes studied. Moreover, the copy number of each allele is twice in Pam than in Paa. This does not fit with Pam being a diploid, and leads us to conclude that Pam is probably a tetraploid. In addition, the sequences of the PAM1 and PAM2 alleles for the four genes studied by loos et al. (2006) were highly divergent with $2.2 \%$ to $8.6 \%$ base pair polymorphism, which suggests that $P a m$ is the result of an interspecific hybridization between two unknown Phytophthora species, which we will refer to as Pm1 and Pm2 for convenience. Pam could have resulted either from a fusion of unreduced (2n) gametes of both Pam1 and Pam2, or from a genome duplication following a fusion of normally reduced gametes (Fig. 4). Finding the putative progenitors of Pam remains a challenge. Survey of Phytophthora communities in rivers or soil of poorly investigated regions might help to 
identify Pm1 and Pm2 and would shed light on the evolutionary history of the P. alni complex.

The diploid level of Pau that was inferred in previous studies (loos et al., 2006; Aguayo et al., 2013) is in agreement with our results since a low variation of nuclear DNA content within Pau was found. We therefore assumed that the origin of Paa has resulted from the hybridization between the diploid Pau and the allotetraploid Pam. Given that Paa possesses half of the genome of both parents, it can be regarded as an allotriploid hybrid or an aneuploid, near-triploid hybrid as Brasier et al. (1999) reported the occurrence of missing chromosomes. As a result, it is not an allopolyploid species resulting from the merging of the parental genomes (Restrepo et al. 2014); Paa can be instead considered to be a homoploid hybrid since it was formed through hybridization without chromosome doubling (Abbott et al., 2010; Buerkle, 2000; Rieseberg, 1997).

\subsection{Estimation of the total DNA content of the three taxa}

According to the terminology defined by Greilhuber et al. (2005) and the flow cytometry analysis performed in this study, the $2 \mathrm{C}$ genomic DNA content was $0.384 \mathrm{pg}$ for Paa, 0.453 pg for Pam and $0.303 \mathrm{pg}$ for Pau. This means that the monoploid genome size (1Cx-value) of Paa, Pam and Pau would be of $119 \mathrm{Mbp}, 112 \mathrm{Mbp}$ and $144 \mathrm{Mbp}$, respectively (Doležel et al., 2003). It is higher than the genome size of $P$. ramorum (65 Mbp, Tyler et al., 2006, or $71 \mathrm{Mbp}$, Vercauteren et al., 2011) or P. sojae (95 Mbp, Tyler at al., 2006) but lower than that of $P$. infestans (240 Mbp, Haas et al., 2009).

Although Paa isolates were collected throughout Europe, no intraspecific DNA content variation was found, confirming that the hybridization event is quite recent.

\subsection{Triploidy and homoploid speciation in fungi or fungal-like species}

Not surprisingly, most of triploids reported in the literature belong to the plant kingdom (Ramsey and Schemske, 1998). They occur either within species (autotriploidy) or between two distinct species (allotriploidy) and result from the fusion of a normally reduced gamete $(n)$ from a diploid species with a $2 n$ gamete from a diploid (unreduced gamete) or from a tetraploid species (Hegarty and Hiscock, 2008), as found in this work for Paa. The formation of the allotriploid Paa is quite remarkable since very few triploids have been described in fungi or fungal-like species, most of them being autotriploids, as in the genus Candida, Saccharomyces and Allomyces (Albertin and Marullo, 2012).

Although much less frequent than allopolyploid speciation in plants, homoploid hybrid speciation has also been described in plants, in particular Helianthus sp. and Senecio sp., and in animals (Abbott et al., 2010; Hegarty et al., 2009; Mallet, 2007; Liu et al., 2014). In fungi, homoploid speciation has rarely been demonstrated (Restrepo et al. 2014): itwas described for yeast (Grey et al., 2002), Microbotryum sp. (Devier et al., 2010) and Melampsora sp. (Newcombe et al., 2000; Frey et al., 2005). A major problem for homoploids as well as for triploids is sterility or, at least, a severe reduction in fertility that occurs when parental chromosomes are too dissimilar to correctly pair up at meiosis (Buerkle et al., 2000; Hegarty and Hiscock, 2008). This explains the low oospore (Phytophthora sexual spore) viability observed in Paa, the high level of abortion and the absence of germination in the over 4000 oospores analyzed (Delcán and Brasier, 2001). Because it results in new genotypic combinations and often occurs together with chromosome loss and chromosomal rearrangements, homoploid speciation also often leads to ecological divergence from the progenitors, with adaptation of the hybrid to new habitats (Abbott et al., 2010; Bertier et al., 2013). Indeed, all well-described homoploid hybrids occur in habitats that are distinct from their parental species such as the three diploid Helianthus hybrid species $H$. anomalus, $H$. deserticola and $H$. paradoxus which colonize more extreme habitats than their parents, or the fish Gila seminude, native to the United States, which is found in close but distinct rivers than its parental species (Gross and Rieseberg, 2005). For P. alni, the hybridization event produced an aggressive pathogen, $\mathrm{Paa}$, which invaded European riparian alder forests while 
both progenitors remain infrequent and have not been associated to severe alder decline (Aguayo et al., 2013; Brasier et al., 2004; Jung and Blaschke 2004). Moreover, the ecological niche of the hybrid and its parents appear to be different as Pau is present along small watercourses at higher elevation (Štěpanková et al., 2013) and at higher latitude (Redondo et al., 2015) compared to Paa. We found comparable results in the Marais Poitevin in western France for Pam; among 111 stands investigated throughout the catchment, Pam was detected exclusively upstream $(n=7)$, while Paa was found only in the lower part of the river catchment ( $n=63$, Husson, unpublished results).

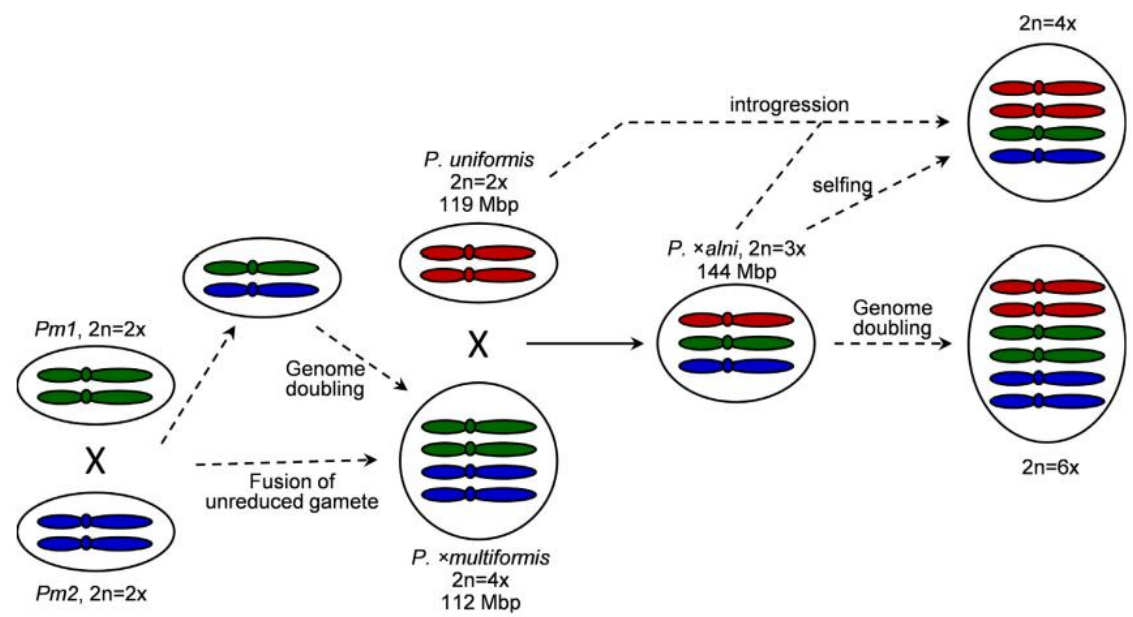

Fig. 4: Hypothetical scenarios for the interspecific hybridization events leading to the triploid species Phytophthora $\times$ alni, for the origin of the progenitor $P$. $\times$ multiformis and about possible future evolutions of $P$. $\times$ alni. Dashed lines indicate hypothetical events involving undescribed species, including Pm1 and Pm2 as hypothetical parents of $P$. x multiformis. In red, allele PAU; in green, allele PAM1; in blue, allele PAM2. Ploidy level and monoploid genome size (1Cx-value) are indicated for each species. Adapted from Hegarty and Hiscock (2008).

The potential for evolution of a triploid homoploid hybrid depends on its degree of fertility (Ramsey and Schemske, 1998). It may contribute to the formation of a tetraploid either by selfing or by backcrossing to the diploid parent (Comai, 2005). Such a mechanism could occur for $P$. alni if the triploid Paa would backcross with the diploid parent $P a u$, yielding an allotetraploid progeny (Fig. 4). It may be worthy to note that few isolates could not be clearly attributed to one of the taxa, sharing properties of the three taxa. These isolates represented about $0.5 \%$ of a collection of 519 tested isolates (31 Pam, $34 \mathrm{Pau}$ and $451 \mathrm{Paa}$, Aguayo, 2012). We did not clearly determine their nature. A hypothesis would be that they represent evolution after $\mathrm{Paa}$ formation, either by subsequent loss of chromosomes or backcross with one of the parents. The fact that the unassigned isolates PA340 and PA616 exhibit a total DNA content close to that of Paa, and that they differ from Paa only by a few alleles missing, is consistent with the hypothesis of a chromosome loss. A large variation in DNA content seems to be common in Phytophthora hybrids (Bertier et al., 2013). Another possible evolution after the formation of a triploid homoploid hybrid would be genome duplication leading to an allohexaploid (Fig. 4). This evolution could restore the fertility of the hybrid as each chromosome would then have an exact homolog (Giraud et al., 2008; Hegarty and Hiscock, 2008). Such restoration of fertility in Paa would, in turn, further increase its evolutionary potential. Moreover, absence of viable sexual spores has been shown to be associated with poor overwintering of $P$. alni after cold winters, with important epidemiological consequences (Aguayo et al, 2014). Thus, detecting these possible 
evolutions of Paa is critical, and the methods used in this study, i.e. quantitative PCR and flow cytometry, would be a useful tools for that purpose.

\subsection{Taxonomy}

Formerly called alder Phytophthora (Brasier et al., 1995), the causal pathogen of alder decline was later taxonomically described as $P$. alni (Brasier et al., 2004). Due to the phenotypic and genotypic distinctive traits within the $P$. alni complex, the taxa were split into three subspecies called $P$. alni subsp. alni and its variants $P$. alni subsp. multiformis and $P$. alni subsp. uniformis, which were both considered to have been generated by genetic breakdown or by backcrosses involving Paa (Brasier et al., 1999, 2004).

However, both Pam and Pau have been found as standalone species, Pau as a native species in North America and Pam in different rivers of France (Aguayo 2012; Aguayo et al, 2013). Moreover, numerous molecular analyses, based on sequence polymorphism of four single-copy nuclear, two mitochondrial and six elicitin genes (loos et al., 2006, 2007b), on nine microsatellite loci (loos et al., 2007a) and on expression pattern of isozymes and mitochondrial DNA (Bakonyi et al., 2007; Nagy et al., 2003), clearly showed that Pau and Pam are the parental species of the hybrid Paa.

Based on these results and on the present study, which clarifies the ploidy level of $P a a$ and Pam, we propose to raise Paa, Pau and Pam to species status and to rename them as follows:

Phytophthora xalni (Brasier \& S. A. Kirk) Husson, loos \& Marçais, nothosp. nov.

Basionym Phytophthora alni subsp. alni Brasier \& S. A. Kirk, Mycological Research 108(10): 1172-1186. 2004

Phytophthora uniformis (Brasier \& S. A. Kirk) Husson, loos \& Aguayo, comb. nov.

Basionym Phytophthora alni subsp. uniformis Brasier \& S. A. Kirk, Mycological Research 108(10): 1172-1186. 2004

Phytophthora $\times$ multiformis (Brasier \& S. A. Kirk) Husson, loos \& Frey, nothosp. nov.

Basionym Phytophthora alni subsp. multiformis Brasier \& S. A. Kirk, Mycological Research 108(10): 1172-1186. 2004

These species can be identified following loos et al (2006) using the allele-specific primer pairs TRP-PAU-F/-R, RAS-PAM1-F/-R and RAS-PAM2-F/-R, $P$. uniformis being detected with TRP-PAU-F/-R, $P$. x multiformis with RAS-PAM1-F/-R and RAS-PAM2-F/-R and $P$. $\times$ alni with all three primers pairs. Finally, it has to be pointed out that, although very infrequent, some isolates cannot be clearly attributed to one of the three species using these tools.

\section{Acknowledgements}

This work was supported by grants from INRA, the Région Lorraine (France), the Agence Nationale de la Recherche (ANR 07-BDIV-003, Emerfundis program), the FEDER (Interreg IV-A Grande Région Ecolirimed program). We thank the colleagues listed in Table 1 for sharing Phytophthora sp. isolates. We are grateful to Prof. Dr. Johann Greilhuber (University of Vienna), Cyril Dutech (INRA Bordeaux-Aquitaine) and to Katherine Hayden for helpful comments and Thomas Munier for technical assistance. The UMR1136 is supported by a grant overseen by the French National Research Agency (ANR) as part of the "Investissements d'Avenir" program (ANR-11-LABX-0002-01, Laboratory of Excellence ARBRE). 


\section{References}

Abbott, R.J., Hegarty, M.J., Hiscock, S.J., Brennan, A.C., 2010. Homoploid hybrid speciation in action. Taxon 59, 1375-1386.

Aguayo, J., 2012. Etude des conditions de l'émergence de Phytophthora alni sur l'aulne glutineux. $\mathrm{PhD}$ dissertation. University of Lorraine. $175 \mathrm{pp}$.

Aguayo, J., Adams, G. C, Halkett, F., Catal, M., Husson, C., Nagy, Z. A., Marçais, B. Frey, P., 2013. Strong genetic differentiation between North American and European populations of Phytophthora alni subsp. uniformis. Phytopathology 103, 190-199.

Aguayo, J., Elegbede, F., Husson, C., Saintonge, F.X., Marçais., B., 2014. Modelling climate impact on an emerging disease, Phytophthora alni induced alder decline. Glob. Change Biol. 20, 32093221 .

Albertin, W., Marullo, P., 2012. Polyploidy in fungi: evolution after whole-genome duplication. Proc. R. Soc. B. 279, 2497-2509.

Anderson, C.L., Kubisiak, T.L., Nelson, C.D., Smith, J.A., Davis, J.M., 2010. Genome size variation in the pine fusiform rust pathogen Cronartium quercuum f.sp. fusiforme as determined by flow cytometry. Mycologia 102, 1295-1302.

Arrigo, N., Barker, M.S., 2012. Rarely successful polyploids and their legacy in plant genomes. Curr. Opin. Plant Biol. 15, 140-146.

Bakonyi, J., Nagy, Z.A, Ersek, T., 2007. A novel hybrind with the nuclear background of Phytophthora alni subsp. alni exhibits a mitochondrial DNA profile characteristic of $P$. alni subsp. uniformis. Acta Phytopathol. Hun. 42, 1-7.

Bertier, L., Leus, L., D'Hondt, L., de Cock, A.W.A.M., Höfte, M., 2013. Host adaptation and speciation through hybridization and polyploidy in Phytophthora. Plos One 8, e85385.

Brasier, C. M., 1995. Episodic selection as a force in fungal microevolution, with special reference to clonal speciation and hybrid introgression. Can. J. Bot. 73, 1213-1221.

Brasier, C.M., Rose, J., Gibbs, J.N., 1995. An unusual Phytophthora associated with widespread alder mortality in Great Britain. Plant Pathol. 44, 999-1007.

Brasier, C.M., Cooke, D.E.L., Duncan, J.M., 1999. Origin of a new Phytophthora pathogen through interspecific hybridization. Proc. Natl. Acad. Sci. USA 96, 5878-5883.

Brasier, C.M., 2000. The rise of the hybrid fungi. Nature 405, 134-135.

Brasier, C.M., 2001. Rapid evolution of introduced plant pathogens via interspecific hybridization. Bioscience 51, 123-133.

Brasier, C.M., Kirk, S.A., Delcan, J., Cooke, D.E.L., Jung, T., Man in't Veld, W.A., 2004. Phytophthora alni sp. nov. and its variants: designation of emerging heteroploid hybrid pathogens spreading on Alnus trees. Mycol. Res. 108, 1172-1184.

Buerkle, C.A., Morris, R.J., Asmussen, M.A., Rieseberg, L.H., 2000. The likelihood of homoploid hybrid speciation. Heredity $84,441-451$.

Burson, B.L., Actkinson, J.M., Hussey, M.A., Jessup, R.W., 2012. Ploidy determination of buffel grass accessions in the USDA National Plant Germplasm System collection by flow cytometry. S. Afr. J. Bot. 79, 91-95.

Catal, M., King, L., Tumbalam, P., Wiriyajitsomboon, P., Kirk, W.W., Adams, G.C., 2010. Heterokaryotic nuclear conditions and a heterogeneous nuclear population are observed by flow cytometry in Phytophthora infestans. Cytometry A 77A, 769-775.

Comai, L, 2005. The advantages and disadvantages of being polyploid. Nat. Rev. Genet. 6, 836-846.

Delcán, J., Brasier, C.M., 2001. Oospore viability and variation in zoospore and hyphal tip derivatives of the hybrid alder Phytophthoras. Forest Pathol. 31, 65-83.

Devier, B., Aguileta, G., Hood, M.E., Giraud, T., 2010. Phylogenies of pheromone receptor genes in the Microbotryum violaceum species complex: insights into possible ancient events of speciation by hybridization. Mycologia 102, 689-696.

Desprez-Loustau, M.L., 2009. The alien fungi of Europe. In: Drake, J.A. (Eds.), DAISIE Handbook of alien species in Europe. Springer, Dordrecht, pp. 15-28.

D'Hondt, L., Höfte, M., Van Bockstaele, E., Leus, L., 2011. Applications of flow cytometry in plant pathology for genome size determination, detection and physiological status. Mol. Plant Pathol. $12,815-828$. 
Doležel, J., Bartoš, J., Voglmayr, H., Greilhuber, J., 2003. Nuclear DNA content and genome size of trout and human. Cytometry A $51 \mathrm{~A}, 127-128$.

Doležel J., Bartoš J., 2005. Plant DNA flow cytometry and estimation of nuclear genome size. Ann. Bot. 95, 99-110.

Frey, P., Gérard, P., Feau, N., Husson, C., and Pinon, J., 2005. Variability and population biology of Melampsora rusts on poplars. In: M. H. Pei, A. R. McCracken, (Eds.), Rust diseases of willow and poplar, 2005, pp. 63-72.

Gibbs, J.N., Lipscombe, M.A., Peace, A.J., 1999. The impact of Phytophthora disease on riparian populations of common alder (Alnus glutinosa) in southern Britain. Eur. J. Forest Pathol. 29, 3950.

Giraud, T., Refregier, G., Le Gac, M., de Vienne, D.M., Hood, M.E., 2008. Speciation in fungi. Fungal Genet. Biol. 45, 791-802.

Goss, E. M., Cardenas, M. E., Myers, K., Forbes, G. A., Fry, W. E., Restrepo, S., Grünwald, N. J., 2011. The plant pathogen Phytophthora andina emerged via hybridization of an unknown Phytophthora species and the Irish Potato Famine pathogen, P. infestans. Plos One. 6, e24543.

Greilhuber, J., Doležel, J., Lysak, M.A., Bennett, M.D., 2005. The origin, evolution and proposed stabilization of the terms 'genome size' and ' $\mathrm{C}$-value' to describe nuclear DNA contents. Ann. Bot. 95, 255-260.

Gross, B.L., Rieseberg, L.H., 2005. The ecological genetics of homoploid hybrid speciation. J. Heredity 96, 241-252.

Haas, B.J., Kamoun, S., Zody, M.C., Jiang, R.H.Y., Handsaker, R.E., Cano, L.M., Grabherr, M., Kodira, C.D., Raffaele, S., Torto-Alalibo, T., et al., 2009. Genome sequence and analysis of the Irish potato famine pathogen Phytophthora infestans. Nature 461, 394-398.

Hegarty, M.J., Hiscock, S.J., 2008. Genomic clues to the evolutionary success of polyploid plants. Curr. Biol. 18, 435-444.

Hegarty, M.J., Barker, G.L., Brennan, A.C., Edwards, K.J., Abbott, R.J., Hiscock, S.J., 2009. Extreme changes to gene expression associated with homoploid hybrid speciation. Mol. Ecol. 18, 877889.

Inderbitzin, P., Davis, R. M., Bostock, R. M., Subbarao, K. V., 2011. The ascomycete Verticillium longisporum is a hybrid and a plant pathogen with an expanded host range. Plos One. 6, e18260.

loos, R., Husson, C., Andrieux, A., Frey, P., 2005. SCAR-based PCR primers to detect the hybrid pathogen Phytophthora alni and its subspecies causing alder disease in Europe. Eur. J. Plant Pathol. 112, 323-335.

loos, R., Andrieux, A., Marçais, B., Frey, P., 2006. Genetic characterization of the natural hybrid species Phytophthora alni as inferred from nuclear and mitochondrial DNA analyses. Fungal Genet. Biol. 43, 511-529.

loos, R., Barrès, B., Andrieux, A., Frey P., 2007a. Characterization of microsatellite markers in the hybrid Phytophthora alni subsp. alni and crossamplification with related taxa. Mol. Ecol. Notes 7, 133-137.

loos R., Panabières, F., Industri, B., Andrieux, A., Frey, P., 2007b. Distribution and expression of elicitin genes in the interspecific hybrid oomycete Phytophthora alni. Appl. Environ. Microbiol. 73, $5587-5597$.

Jeyaprakash, A., Hoy, M.A., 2009. The nuclear genome of the phytoseiid Metaseiulus occidentalis (Acari: Phytoseiidae) is among the smallest known in arthropods. Exp. Appl. Acarol. 47, 263273.

Jung, T., Blaschke, M., 2004. Phytophthora root and collar rot of alders in Bavaria: distribution, modes of spread and possible management strategies. Plant Pathol. 53, 197-208.

Liu, B., Abbott, R. J., Lu, Z., Tian, B., Liu, J., 2014. Diploid hybrid origin of Ostryopsis intermedia (Betulaceae) in the Qinghai-Tibet Plateau triggered by Quaternary climate change. Mol Ecol. 23, 3013-27.

Mounsey, K.E., Willis, C., Burgess, S.T.G., Holt, D.C, McCarthy, J., Fischer, K., 2012. Quantitative PCR-based genome size estimation of the astigmatid mites Sarcoptes scabiei, Psoroptes ovis and Dermatophagoides pteronyssinus. Parasit.Vectors 5, 3 doi:10.1186/1756-3305-5-3.

Mallet, J., 2007. Hybrid speciation. Nature 446, 279-283.

Man in 't Veld, W. A., de Cock, A. W. A. M., Summerbell, R. C., 2007. Natural hybrids of resident and introduced Phytophthora species proliferating on multiple new hosts. Eur. J . Plant Pathol. 117, 25-33. 
Man in 't Veld, W.A., Rosendahl, K.C.H.M., Hong, C., 2012. Phytophthora $\times$ serendipita sp. nov. and P. $\times$ pelgrandis, two destructive pathogens generated by natural hybridization. Mycologia 104, $1390-1396$.

Nagel, J.N., Gryzenhout, M., Slippers, B., Wingfield, M.J., Hardy, G.E.St.J., Stukely, M.J.C., Burgess, T.I., 2013. Characterization of Phytophthora hybrids from ITS clade 6 associated with riparian ecosystems in South Africa and Australia. Fungal Biol. 117, 329-347.

Nagy, Z.A., Bakonyi, J., Ersek, T., 2003. Standard and Swedish variant types of the hybrid alder Phytophthora attacking alder in Hungary. Pest Manag. Sci. 59, 484-492.

Newcombe, G., Stirling, B., McDonald, S., Bradshaw, H.D., Jr, 2000. Melampsora ×columbiana, a natural hybrid of M. medusae and M. occidentalis. Mycol. Res. 104, 261-274.

Newcombe, G., Stirling, B., Bradshaw, H.D., Jr, 2001. Abundant pathogenic variation in the new hybrid rust Melampsora × columbiana. Phytopathology 91, 981-985.

Olson, A., Stenlid, J. 2002. Pathogenic fungal species hybrids infecting plants. Microbes Infect. 4, 1353-1359.

Otto, S.P., 2007. The evolutionary consequences of polyploidy. Cell 131, 452-462.

Otto, S.P., Whitton, J., 2000. Polyploid incidence and evolution, Annu. Rev. Genet. 34, 401-427.

Parisod, C., Holderegger, R., Brochmann, C., 2010. Evolutionary consequences of autopolyploidy. New Phytol. 186, 5-17.

Ramsey, J., Schemske, D. W., 1998. Pathways, mechanisms, and rates of polyploid formation in flowering plants. Annu. Rev. Ecol. Syst. 29, 467-501.

Redondo, M.A., Boberg, J. , Olsson, C.H.B., Oliva, J., 2015. Winter conditions correlate with Phytophthora alni subspecies distribution in Southern Sweden. Phytopathology, in press.

Restrepo, S., Tabima, J.F., Mideros,M.F., Grünwald, N.J., Matute, D.R., 2014. Speciation in Fungal and Oomycete Plant Pathogens. Annu. Rev. Phytopathol. 52, 289-316.Rieseberg, L.H., 1997. Hybrid origins of plant species. Annu. Rev. Ecol. Syst. 28, 359-389.

Rozen, S., Skaletsky, H., 2000. Primer3 on the WWW for general users and for biologist programmers. In: Krawetz, S., Misener, S. (Eds.), Bioinformatics methods and protocols: methods in molecular biology. Humana Press, Totowa, pp. 365-386.

Schardl, C.L., Craven, K.D. 2003. Interspecific hybridization in plant associated fungi and oomycetes: a review. Mol. Ecol. 12, 2861-2873.

Štěpanková, P., Černý, K., Strnadová, V., Hanáček, P., Tomšovský, M., 2013. Identification of Phytophthora alni subspecies in riparian stands in the Czech Republic. Plant Protect. Sci. 49, 3 10.

Stukenbrock, E., McDonald, B., 2008. The origins of plant pathogens in Agro-Ecosystems. Annu. Rev. Phytopathol. 46, 75-100.

Thoirain, B., Husson, C., Marçais, B., 2007. Risk factors for the Phytophthora-induced decline of alder in northeastern France. Phytopathology 97, 99-105.

te Beest, M., Le Roux, J.J., Richardson, D.M., Brysting, A.K., Suda, J., Kubešová, M., Pyšek, P., 2011. The more the better? The role of polyploidy in facilitating plant invasions. Ann. Bot. 109, $19-45$.

Tyler, B.M., Tripathy, S., Zhang, X., Dehal, P., Jiang, R.H.Y., Aerts, A., Arredondo, F.D., Baxter, L., Bensasson, D., Beynon, J.L., et al., 2006. Phytophthora genome sequences uncover evolutionary origins and mechanisms of pathogenesis. Science 313, 1261-1266.

Vercauteren, A., Boutet, X., D'hondt, L., Van Bockstaele, E., Maes, M., Leus, L., Chandelier, A., Heungens, K., 2011. Aberrant genome size and instability of Phytophthora ramorum oospore progenies. Fungal Genet. Biol. 48, 537-543.

Walker, D.J., Monino, I., Correal, E., 2006. Genome size in Bituminaria bituminosa (L.) C.H. Stirton (Fabaceae) populations: separation of "true" differences from environmental effects on DNA determination. Environ. Exp. Bot. 55, 258-265.

Wilhelm, J., Pingoud, A., Hahn, M., 2003. Real-time PCR-based method for the estimation of genome sizes. Nucleic Acids Res., 31, e56. 